\title{
PROBLEMS OF CONSERVATION AND USE OF AGRICULTURAL LAND IN URBAN AGGLOMERATIONS
}

\author{
Anastasiya Kondolskaya ${ }^{1}$, Dariya Vasilieva ${ }^{1}$, Velta Parsova ${ }^{2}$, Dmitry Antropov ${ }^{3}$ \\ ${ }^{1}$ Samara State University of Economics, Russia; ${ }^{2}$ Latvia University of Life Sciences and Technologies, \\ Latvia; ${ }^{3}$ State University of Land Use Planning, Russia \\ kondolskaya@icloud.com, vasilievadi@mail.ru,velta@parsova.lv, antropovzem@gmail.com
}

\begin{abstract}
Urban agglomerations are actively developing concentrations of populated areas, which sometimes consist of ten's or even hundreds of populated areas, including rural settlements. Within the agglomeration, strong economic, social, labor and other connections are formed. At present, the trends of consolidation of cities into large agglomerated spaces are the subject of discussions at various forums, congresses and conferences on global scale. The processes of urbanization, expansion of settlements, population increase are always closely connected with the conservation and use of agricultural land, which makes the topic of research relevant. The article describes the practice of use of agricultural land of the largest agglomerations: the principles of using especially valuable land are presented, methods of preserving the territories used for agricultural purposes are analysed. Details of conservation and use of agricultural land are discussed in the article on the example of the Samara-Tolyatti agglomeration - the largest polycentric agglomeration of the Russian Federation. On the territory of this agglomeration, there is especially valuable agricultural land, significant area elements of the natural-ecological framework, which should be protected. Economic assessment of the use of agricultural land within the boundaries of agglomeration has been made and comparative analysis of use of agricultural land located within the boundaries of settlements has been presented. Also the features of the use of agricultural land depending on distance up to agglomeration centre have been discussed. The result of investigation is the development of conceptual proposals, on the basis of which it is possible to create an integrated methodology for evaluating alternatives of use of agricultural land for the purpose of rational land management in the agglomeration.
\end{abstract}

Keywords: expansion, municipal districts, preservation, urban agglomeration, valuable land.

\section{Introduction}

In the world the trend of development in last century has been the growing role of cities. Process of urbanization has affected all countries of the world and is characterized, firstly, by the rapid growth of the urban population, and, secondly, by the rapid growth of large cities. In 1900, $13 \%$ of the population in the world lived in cities, in $1950-29 \%$, in $1990-46 \%$, and in 2010 - more than $50 \%$. According to forecasts, by 2030 the urban population will increase to 5 billion people. For global practice agglomerations are not novelty, but for Russia such a territorial-economic union of cities and other municipalities is a fairly new phenomenon. Russia just in twenty-first century embarked formation of pilot projects, such as, for example, development of Krasnoyarsk agglomeration. Change of the settlement system in favour of the cities is significant characteristic and component of the economic dynamics of Russia. Cities are characterized by a more developed and flexible labour market, and if the city is larger, ability to meet the demand from the business is greater. The study of the socio-economic and territorial development of Russia shows that development of cities as well as the emergence and further growth of agglomerations will continue and increase [1]. At the same time, more than $60 \%$ of the most productive irrigated arable land in the world is located near urban agglomerations, which creates high competition between the agricultural use of the territory and its involvement in urban planning processes. The importance of preserving highly valuable and fertile land has been repeatedly noted by Russian and foreign scientists A.Varlamov, S.Galchenko, N.Kresnikova, R.Chand, S. Parappurathu et al.

The study of scientific literature shows that the main areas of population growth are agglomerations of Asia and Africa - Shanghai, Tokyo, Karachi, Delhi, Cairo, Lagos [2]. Agriculture is predominant in total GDP for many of listed agglomerations. Many of authors present a forecast for growth of the largest agglomerations of the world by 2030 and reduction of areas of arable land around them. This forecast is rather pessimistic, therefore the study of the conservation and use of agricultural land of urban agglomerations is of particular importance [3]. It is proved that the development of urban areas on agricultural land increases land degradation [4]. Uncontrolled urbanization increases energy consumption, raises the cost of infrastructure development and negatively affects the condition of environment [5]. 
The purpose of article is the investigation of problems of use of agricultural land in situation of growth of urban agglomerations on the example of the Samara-Tolyatti agglomeration.

According to the results of the analysis of statistical data, national reports and statements on conditions and land use of the region, materials of urban planning and territorial development of cities within the agglomeration, the dependence of agricultural production on the distance of farms from centres of agglomeration was identified. There were identified areas of agricultural land exposed to high risks of elimination in connection with the process of urbanization. Necessity of development and implementation of amendments to the legislative acts at the federal level contributing to the protection of especially valuable agricultural land has been confirmed.

\section{Materials and methods}

Publicly available materials of the Federal State Statistics Service (Rosstat), national reports on the status and use of land both in the Russian Federation and in the Samara region have been used for analysis. Territorial planning materials of the cities included in Samara-Tolyatti agglomeration, general plans and regulations on land use and development also were studied. Current situation of agricultural land around urban areas, using remote sensing data analysis, was studied. There are identified areas of arable land which can disappear because of current urbanization.

\section{Results and discussion}

1. Currently there are 50 urban agglomerations in the Russia, 43 or $80 \%$ of them are located in the European part of the country. At the same time, $52 \%$ of the population of Russia lives in agglomerations and large cities. There has been created $55 \%$ of GDP. Importance of development of urban agglomerations was understood at the federal level, therefore in 2008 the Concept for the long-term socio-economic development of the Russian Federation for the period up to 2020 was adopted. This document defined the main directions and strategic development guidelines, including regional level. Agglomerations should take a significant place in the spatial development of the Russian Federation, being the poles of economic growth and reproduction of human capital [6].

2. According to the latest report of the Ministry of Agriculture, in Russia has been observed reduction of the area of agricultural land due to its transformation into build-up area. Data of Rosreestr show that in period 2009 - 2016 area of agricultural land category decreased by 16 million hectares (more than $4 \%$ ). In 2016 more than 45 thousand hectares were transformed into build-up area. The greatest decline was observed on the territory of Bashkortostan (7 thousand hectares), Krasnodar (6 thousand hectares), Chouvashia (4.3 thousand ha) [7]. In Samara region area of agricultural land category also has been decreased. Analysis of regional reports on the status and use of land in Samara region showed small but fairly regular decrease, mainly due to transformation into build-up area - in 2008 - by 6.2 thousand hectares, in 2009 - by 7.2 thousand hectares, in 2013 - by 0.7 thousand hectares and in 2016 - by 0.2 thousand hectares. Thus, over past 10 years area of agricultural land has decreased from 4106.3 thousand hectares in 2008 to 4067.2 thousand hectares in 2018) due to growth of cities and other settlements of the SamaraTolyatti agglomeration [8].

3. The territorial development of the largest polycentric agglomeration of the Russian Federation Samara-Tolyatti agglomeration has been studied. It is the third largest agglomeration (after Moscow and St. Petersburg), it is unique dual-core (polycentric) agglomeration. Samara city and Tolyatti city belong to the category of the largest cities (Fig.1) [9].

4. Within boundaries of Samara-Tolyatti agglomeration are located 8 of 10 urban districts and 9 of 27 municipal districts of the Samara region, 2.7 million people or $86 \%$ of the region's population live here. $83 \%$ of industrial and $49 \%$ of agricultural products has been produced, as well as $88 \%$ of investments have been mastered on the territory of the agglomeration. Samara-Tolyatti agglomeration is a territory with significant inter-settlement spaces, many of them have been used for agricultural development (Table 1). Table 1 show that area of land allocated for production of agricultural products on territory of Samara-Tolyatti agglomeration in period 2015 - 2017 increased by about $3 \%$. Involvement of additional territories was carried out due to investments 
of municipal districts. With increase in the total area of arable land, in the region remains the problem of loss of especially valuable and fertile land.

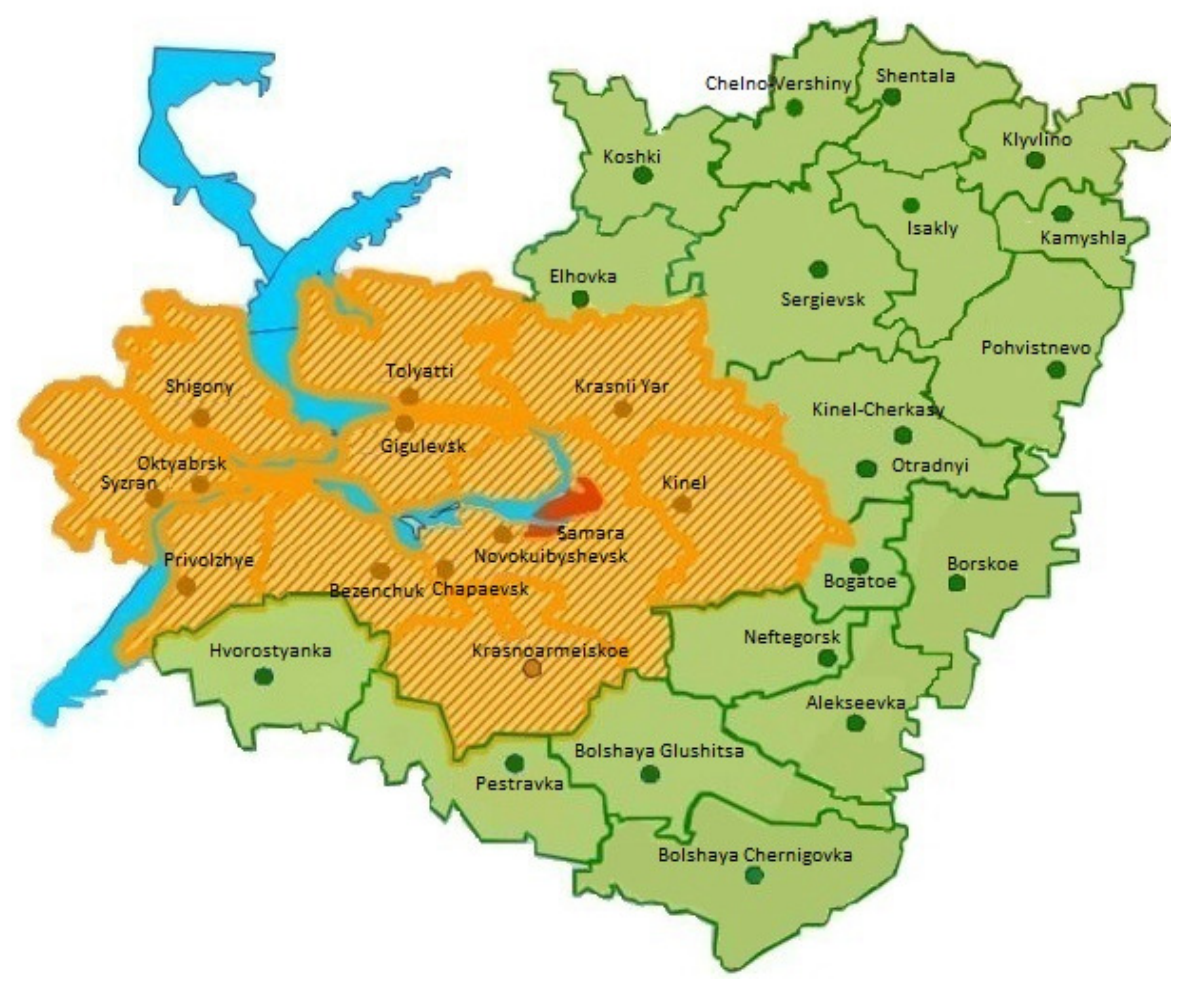

Fig. 1. Territory of Samara-Tolyatti agglomeration

\section{Changes in crop areas in the cities and municipal districts} of the Samara-Tolyatti agglomeration

\begin{tabular}{|c|c|c|c|c|c|}
\hline \multirow{2}{*}{ Zone } & \multirow{2}{*}{ Area, km $\mathbf{k m}^{\mathbf{2}}$} & \multicolumn{3}{|c|}{ Crop areas, thousand ha } & \multirow{2}{*}{$\begin{array}{c}\text { Percentage of total area } \\
\text { (on 01.01.18.) }\end{array}$} \\
\cline { 3 - 5 } & & $\mathbf{2 0 1 5}$ & $\mathbf{2 0 1 6}$ & $\mathbf{2 0 1 7}$ & 0.05 \\
\hline Cities & 1643 & 3.2 & 3.0 & 2.3 & 11.06 \\
\hline Municipal districts & 20022 & 627.3 & 643.8 & 646.5 & $X$ \\
\hline Total & 21674 & 630.5 & 646.8 & 648.8 & \\
\hline
\end{tabular}

Territories adjacent to the cities are most subjected to demographic, social and territorial changes. Right here collide short-term market interests, where the land has been viewed as a commodity, and long-term interests, where land is a valuable natural resource. There is an obvious reduction of arable land in all cities of the agglomeration. As a rule, this land is located on outskirts of settlements, and there have been implemented projects of construction of economy-class housing or commercial buildings. Build-up areas are replacing agricultural land use. In most cases, such a liquidation of fertile agricultural land is carried out without looking for alternative options.

Table 2 presents changes in the volume of agricultural production in actual prices in period 20152017 in municipal districts of Samara-Tolyatti agglomeration. About $55 \%$ of production was produced by households, small proportion (about $12 \%$ ) has been produced by farms and individual entrepreneurs. It can be explained with difficulties of small business development in the region.

It has been noted that with increase of area of arable land, the decrease in the volume of production is observed [10]. To describe productivity of land in Samara-Tolyatti agglomeration, volume of agricultural production per hectare was analyzed (Fig. 2). On the basis of obtained data, an obvious dependence of the volume of production per 1 ha of area on remoteness of municipal districts and cities from agglomeration cores can be observed. So, the most remote municipal districts (Shigonskiy, Privolzhskiy, Krasnoarmeyskiy) have the lowest indicators. In our opinion, this is due to 
the fact that high cost of land in the core cities and adjacent municipal districts predetermine the need to obtain maximum profit for the profitability of production.

Table 2

Breakdown of changes in the volume of agricultural production in municipal districts of Samara-Tolyatti agglomeration

\begin{tabular}{|c|c|c|c|}
\hline \multirow{2}{*}{ Municipal districts } & \multicolumn{3}{|c|}{ Production, thousand RUB per thousand hectares } \\
\cline { 2 - 4 } & $\mathbf{2 0 1 5}$ & $\mathbf{2 0 1 6}$ & $\mathbf{2 0 1 7}$ \\
\hline Bezenchukskiy & 9268.2 & 10085.2 & 9264.6 \\
\hline Volzhskiy & 7563.5 & 9096.2 & 8360.8 \\
\hline Kinel'skiy & 8903.2 & 9868.1 & 8696.4 \\
\hline Krasnoarmeyskiy & 4947.2 & 7695.8 & 5775.8 \\
\hline Krasnoyarskiy & 9224.1 & 9520.1 & 8754.5 \\
\hline Privolzhskiy & 6165.0 & 7305.54 & 7093.6 \\
\hline Stavropol'skiy & 17075.5 & 16928.8 & 15481.5 \\
\hline Syzranskiy & 4658.8 & 5539.8 & 5141.6 \\
\hline Shigonskiy & 3359.3 & 3784.5 & 3604.2 \\
\hline Total & $\mathbf{7 9 7 9 4 . 7}$ & $\mathbf{8 9 0 2 7 . 8}$ & $\mathbf{8 1 8 3 3 . 4}$ \\
\hline
\end{tabular}

Urbanization on the territory of Samara-Tolyatti agglomeration is largely associated with growth of urban land in the two largest cities - Samara and Tolyatti. Development of the territory of Samara city has been implemented in accordance with the General Plan adopted in 2008. There was provided transformation of agricultural land into build-up area of state farms "Kriazhi" (250 hectares), "Kozelki" (200 hectares), "Doyki" (341 hectares), etc. For 10 years, that have passed since an implementation of planned in the Master Plan measures, it is possible to see changes that have occurred on the former agricultural land in surroundings of Samara city (Fig. 3).

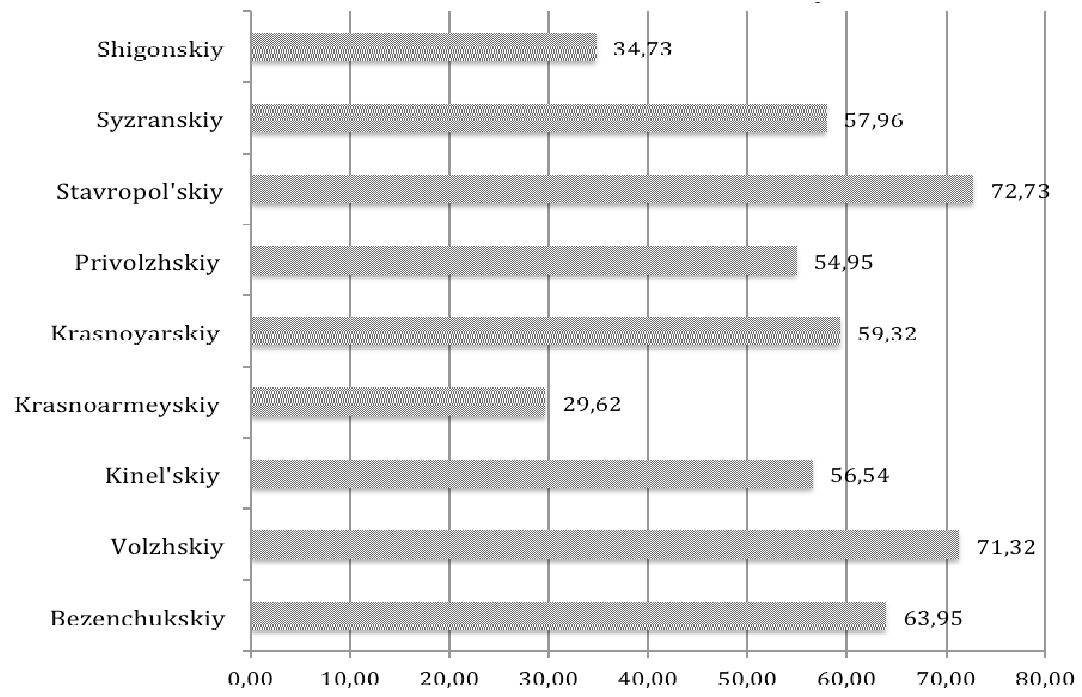

Fig. 2. Volume of agricultural production in thousand of RUB per hectare in Samara-Tolyatti agglomeration

Implementation of projects of residential complexes "Volgar", "Southern City", "KoshelevProject" was carried out in the last decade. As a result, the land, which had high fertility rate and was used for agriculture, was eliminated. Analyzing tendencies of involvement of open land in urban planning process can be assumed that there is high level of risks for land located near residential complexes. There can be seen that on the territory of Samara-Tolyatti agglomeration under action of actively flowing urbanization goes on absorption and transformation of agricultural land into build-up area. Instead of reclamation of land requiring significant financial expenditures for preparation of engineering maintenance, as build-up areas mainly are used arable land and fallow land with comfortable flat topography and low level of groundwater, which is located close to developed road network [11]. It is planned to develop new Master Plan for Samara city, which will determine the growth and development of the city in coming years. 


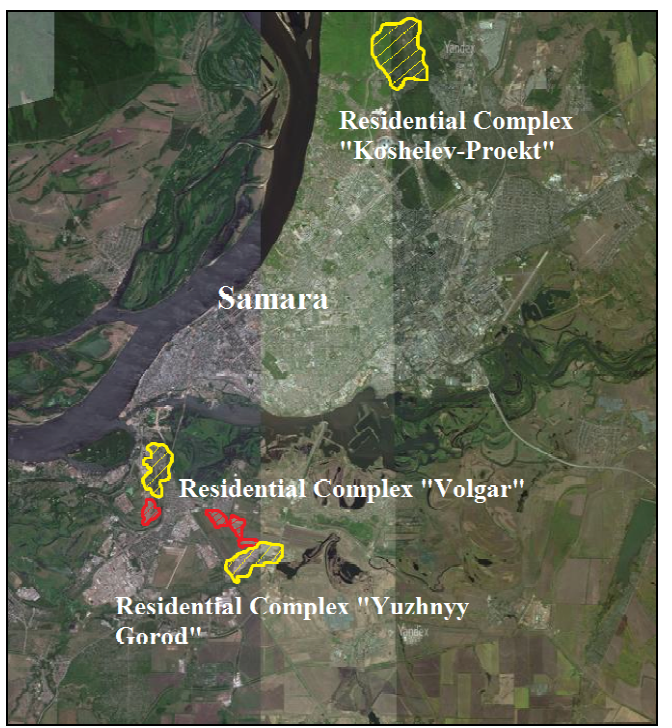

Fig. 3. Existing (in yellow) and planned (in red) build-up areas used for agriculture

Currently Government of the Russia is paying attention to improvement of legal regulation of land relations. Ministry of Economic Development of the Russia has prepared plan for future activities, there have been planned:

- development of Federal Law on allocation of separate territorial zones with especially valuable agricultural land, and establishment of criteria for assignment to such land;

- preparation of report to Government on the performance of work on determining the location of territories with especially valuable agricultural land and inclusion of relevant information into Unified State Register of Real Estate;

- development of Federal Law on creation of the institute of certification of agricultural land for survey of information about conditions and properties of the soil.

Thus, use of high-value and fertile land is highly relevant. In accordance with plans of improvement of legal regulation of land relations, in the near future fundamental changes with aim to preserve agricultural land will take place in this sphere. However, at the moment there are a lot of "problematic" situations associated with use of agricultural land peculiar for territory of the SamaraTolyatti agglomeration and other densely populated areas. There is included massive nature of violations of land use regulations, purchase of land for resale, etc. It leads to increased soil degradation, reduction of crop area, appearance of abandoned land overgrown with weeds and shrubs. It is also possible to observe the violation of farming system and crop rotation. At the agglomeration level, in order to increase use of land, it is necessary to create improved farming system and implement set of measures for their effective development, to carry out an adjustment of on-farm land management in case of change of specialization of agricultural enterprises.

\section{Conclusions}

1. Urbanization processes within territory of Samara-Tolyatti agglomeration are going on rapidly.

2. The uniqueness of the agglomerations of the Russian Federation is the presence of significant amount of land resources, possibility to use inter-settlement space for the development of territories.

3. In the cities of Samara-Tolyatti agglomeration decrease of area of arable land is observed. At the same time there is decline in total volume of agricultural production.

4. In Samara-Tolyatti agglomeration there is direct dependence between volume of agricultural production and remoteness of municipal districts and cities from agglomeration cores.

5. Implementation of the planned measures for improvement of legal regulation of land relations will allow preserve valuable agricultural land by tightening of their legal regime and strengthening of control over their use. 


\section{References}

[1] Мищенко В.В., Мищенко И.В. Городские агломерации: формирование и перспективы развития (на примере Барнаульской агломерации) (Urban agglomerations: formation and development prospects (on the example of the Barnaul agglomeration). Контуры глобальных трансформаций: политика, экономика, право, 2015, №5 (37). (In Russian).

[2] Крупнейшие агломерации мира (The largest agglomerations of the world). [online] [11.03.2019]. Available at: http://www.statdata.ru/largest_cities_world_urban_areas.

[3] Chand, R., and Parappurathu, S. Temporal and Spatial Variations in Agricultural Growthand its Determinants. Economic and Political Weekly, Mumbai, volume 47(26), 2012, pp. 55-64.

[4] Parsova V., Kapostins E. Land Policy in Latvia: Implementation and Evaluation of Results. Proceedings of the 7th international scientific conference "Rural Development 2015: Towards the Transfer of Knowledge, Innovations and Social Progress", Aleksandras Stulginskis University (Lithuania), 2015, Kaunas, [online] [11.03.2019]. Available at: http://conf.rd.asu.lt/index.php /rd/article/view/79/53.

[5] Parsova V., Mamai O., Zudilin S. Assessment of the Efficiency of Use of Agricultural Land: an Example of the Samara Region. Proceedings of the 17th International Scientific Conference "Engineering for Rural Development", 2018, Jelgava, Latvia, pp. 623-629.

[6] Староверова Г.С., Медведев А.Ю. Сельская территория как среда обитания и сфера жизнедеятельности человека (Rural area as a habitat and sphere of human activity). Проблемы развития территории, 2014, No 5 (73). (In Russian).

[7] Доклад о состоянии и использовании земель сельскохозяйственного назначения Российской Федерации в 2016 году. (Report on the status and use of agricultural lands in the Russian Federation in 2016). Москва, 2018. 240 с. (In Russian).

[8] Доклад о состоянии и использовании земель в Самарской области в 2017 году (Report on the conditions and use of land in the Samara region in 2017). Управление Федеральной службы государственной регистрации, кадастра и картографии по Самарской области. Самара, 2018. (In Russian).

[9] Стратегия развития Самарско-Тольяттинской агломерации (Samara-Tolyatti agglomeration development strategy). Министерство экономического развития, инвестиций и торговли Самарской области, 2019. (In Russian).

[10]Показатели муниципальных образований (Municipal indicators). Федеральная служба государственной статистики, 2019. (In Russian).

[11] Khasaev G., Vlasov A., Vasilieva D., Parsova V. Trends of development of agrolandscapes in Samara region as result of land reform. 17th International Scientific Conference Engineering for Rural Development, Proceedings. 2018. Jelgava, Latvia, pp. 630-634. 